\title{
III. Correspondence.
}

1. The Persian for Rouble.

London, August 10th, 1887.

Șrr,

With reference to the Persian IskeNār (paper-rouble), quoted in the issue of the Journal for April, I would suggest that this word seems to be a somewhat irregular, or rather, vulgar plural form of (wكناس askenas (paper-money), which, according to Kasimirski, comes from the Russian word ассигнація assignatsya (French assignat).

\section{Yours truly, •}

T. G. de Gutraddon, Capt.

The Secretary of the Royal Asiatic Society.

\section{The Bibliography of Africa.}

SIR,

London, August 10th, 1887.

Will you allow me to add some information to the Bibliography of Africa for the current year?

Lieut. G. Binger, of the French Marines, has published at Paris, of course in the French language, a Sketch on the Bambara language, as spoken in the Kaarta and the Beledougou, West Sudan: this language belongs to the Mandingo family, and it is the first serious attempt to reduce it to writing. Lieut. Binger's little work contains a short Grammar, many usual phrases, and a Vocabulary of about 2000 words, and is accompanied by an interesting map: this Handbook is a very valuable contribution towards our knowledge of African languages, and it will prove quite useful.

Lieut. Binger is now engaged in travelling from Bakel down tơ the Guinea coast, and he will, no doubt, bring back some interesting notices on the great Mandingo family.

- I am informed that the Roman Catholic Missionaries of the Senegambia have collected and will publish shortly an extensive Dictionary of the Susu language, also belonging to the Mandingo family, and for which we had only an old Vocabulary by Brunton (1802), with Grammar, and a little Grammar by Rev. J. H. Duport.

Yours truly,

T. G. De Guiraddon, $\mathrm{C}_{\triangle \mathrm{Ft}}$.

The Secretary of the Royal Asiatic Society. 